\title{
The Making of New Zealanders
}

By Ron Palenski. Auckland University Press, Auckland, 2012; 382pp.

ISBN 978186940726

Reviewed by Philippa Mein Smith

Ron Palenski is a noted journalist as well as historian. As someone who has written on the history of sport and who runs the New Zealand Hall of Fame, he has a keen interest in national identity, so much so that he wrote a PhD on the subject at the University of Otago. The Making of New Zealanders is based on this thesis, though readers would not have known without being told as Palenski's skill as a writer ensures that the style is vigorous, engaging and accessible. His core question concerns when migrants to New Zealand from England, Ireland, Scotland, Germany and Scandinavia in the nineteenth-century came to see themselves as New Zealanders, and his answer is that national identity materialized earlier than most historians have thought.

This book's publication confirms that there is a developing historiographical debate in this country over the emergence of national identity versus enduring Britishness, beyond the works of Keith Sinclair and James Belich. Palenski sits alongside Sinclair in this debate, but takes issue with Sinclair rather than with Belich. The principal differences between these two nationalist historians are over when national identity emerged among the settlers, and in the nature of the evidence explored beyond sport. Sinclair argued that the Boer War and the 1905 All Black rugby tour of Britain were key moments in the emergence of a national identity whereas Palenski locates the emergence of national feeling earlier, in the final third of the nineteenth-century. To Palenski, Sinclair's timeline of events - Gallipoli included - marks particular moments that showcased national feeling internationally, when local identity formation had already occurred. In Palenski's view, institutions of state lagged behind people's initiatives: 'God Defend New Zealand', for example, first performed in Otago in 1876, only acquired the status of a 'national song' in 1940 and of the national anthem in 1977.

This book's strengths lie in the rich insights and in the entertaining instances of local patriotism and insistence on distinctiveness. Palenski's argument is understandably tilted towards his areas of interest; the two chapters on sport are particularly strong in their account of the adoption of the silver fern and black singlet, while the chapter on the press's role in the circulation of news and as an outlet for New Zealand literature makes an original contribution to knowledge. How New Zealand came to tell the time, adopting a standard time relatively early, in 1868, is another fascinating episode. From a teaching perspective, one of the most useful chapters concerns New Zealand's decision not to become Australia's seventh State in 1901, where Palenski provides an update of Sinclair's argument for why New Zealanders did not become Australians. Throughout, Palenski finds Maori to be a point of difference. Maori were central to not joining Australia and to the adoption of rugby as the national game, starting with the tour by the Natives team in 1888-89; and Maori 'provided a unique dimension' to the colony's 'assertion of independence and innovation' in the late nineteenthcentury (p.164).

The book's arguments, however, are easily contested. Chapter Four attempts to rebut Miles Fairburn's thesis that the case for New Zealand exceptionalism is poor due to New Zealand culture being dominated by imported influences from Australia, the United States and Britain (a consequence of being settled late by Europeans and by the East Polynesian ancestors of Maori). Palenski advances an alternative thesis based on the Treaty of Waitangi, the relationship with the indigenous people, free, universal primary education, and the early vote for women, that is less than convincing because these cultural ingredients all have comparative histories in other settler societies. Since his argument is focused on the beginnings of a national identity in the nineteenth-century, it insufficiently registers recent 
developments such as the revival of the Treaty in the Pakeha storyline, and a resurgence of Maori cultural and political power, which have transformed national consciousness since the 1980s. Missing from Palenski's analysis is an explicit acknowledgment that identity and culture, individual or collective, are dynamic concepts that are constantly in flux, and that his focus is how and when the making of New Zealanders began, as opposed to the continuing process of making and remaking New Zealanders.

Palenski distinguishes between nationalism, which he associates with national interests, and national identity, defined as a feeling and a 'shared sense of belonging' (p.12), when in fact he considers both sentiment and interests; for example in the development of communications through the telegraph and railways. Consideration of both is argued by Australian historians Neville Meaney and Stuart Ward to be important in understanding national identity. Indeed, Palenski's argument is reminiscent of Benedict Anderson's, that a nation has first to imagine itself as a community before it becomes one.

If this book is evaluated on its own terms, then Palenski is to be congratulated for this appealing defence of New Zealand's distinctiveness and for his determined effort to establish when and how pride in that distinctiveness emerged in what became Pakeha culture, especially in sport. I regret, however, that he chose to spar with Sinclair, with whom he disagrees only in the timing of national identity's emergence, rather than with Belich over the latter's thesis of 'recolonisation', which portrays New Zealanders as different in the sense that they saw themselves as 'better Britons'. Had Palenski chosen to engage more with Britishness as an aspect of New Zealandness, this excellent book could have made more of an impact on the way New Zealand history is written. Nonetheless, the emphasis on national identity is a welcome riposte to the current trend towards debunking 'the nation' in the rush to produce transnational histories that emphasize global connections: through its focus on cultural nationalism Palenski's work helps to rebalance New Zealand history, which he portrays in lively - if boysy - interaction with a wider world. 